\title{
Language revitalization and engagements in the Amazon- The case of Apurinã
}

\author{
Sidney da S. Facundes \\ Professor, Graduate Program of Linguistics and Literature, Federal University of Pará, Brazil, sfacundes@gmail.com
}

Pirjo Kristiina Virtanen

Assistant Professor, Indigenous Studies, University of Helsinki, Finland, pirjo.virtanen@helsinki.fi

Marília Fernanda P. de Freitas

Professor, Faculty of Letters, Federal University of Pará,Brazil, mfpf31@yahoo.com.br

Bruna Fernanda S. Lima-Padovani, bflimapadovani@gmail.com

PhD student, Graduate Program of Linguistics and Literature, Federal University of Pará,

Brazil,bflimapadovani@gmail.com

Patrícia do Nascimento Costa, patriciadiletras@gmail.com

Substitute Professor, Faculty of Letters, Federal University of Pará, Campus Bragança,

Brazil, patriciadiletras@gmail.com

\begin{abstract}
Several Indigenous languages of Brazil have few speakers; in at least one case one speaker only (Xipaya), in most cases a few tens (Mekens), in other cases a few hundred (Apurinã), and in rare cases a few thousand (Tikuna). In most cases, the original language is being replaced by the dominant language, Portuguese. In this article, the issues concerning the current state of vitality of Amazonian Indigenous languages will be addressed, as well as resources and strategies available to work with the communities. The aim is to identify the main causes of language loss, and the paths required to maintain these languages in the long run. The Apurinã language, which belongs to the Arawak linguistic family, will be discussed as a point of departure for addressing the issues of revitalization and engagements. The Apurinã people themselves, numbering approximately seven thousand, live mainly along the tributaries of the Purus river in Southwestern Amazonia. It was noticed that better results were achieved through a collaborative work with the community, as the diversity of spoken language could be included in the teaching materials. Furthermore, the Indigenous authors could feel the authorship that also strengthened the adoption of the materials. Yet, more work is still needed to recreate functional domains for the language to be used, and these domains shall include contemporary everyday activities as well as storytelling, rituals and chants, but also the creation of new public spaces for language use. The power relations with the dominant society are also key elements in designing Indigenous languages materials according to the population's interests, and their particular linguistic characteristics.
\end{abstract}

\section{Keywords}

Apurinã, language endangerment, Amazon, revitalization 


\section{Language Diversity in Brazil}

The goal in this essay is to discuss what it means to work with endangered languages and, in particular, the role of research in engaging with, revitalizing, and maintaining Amazonian Indigenous languages. This will done by taking into consideration the history and present of the Amazonian Indigenous peoples from an anthropological perspective, along with the language itself looked at from a linguistic point of view. In addition, the various attempts to produce language teaching materials will be focused on, in a period of over twenty years of work with the Apurinã language communities in the Amazonas state in the Brazilian Amazon.

At the time of European contact, most Brazilian Indigenous languages became extinct either through persecution or the complete decimation of Indigenous peoples. Brazil's Indigenous population today is significantly less than in the past, with the extinction of approximately $75 \%$ of the population over the last 500 years (Moore, Galucio and Gabas Jr., 2008). In addition to the dramatic events of Brazilian history, current Indigenous languages have been threatened by Indigenous people migrating to cities in search of education and employment; the replacement of native languages by the dominant society's language through marriage outside the linguistic group; the low degree of appreciation given to Indigenous languages by the surrounding community, and other such factors (Moore and Gabas Jr., 2006). In spite of this linguistic decrease in the number of languages, Brazil still has a large number of Indigenous languages with wide genetic variety. Moore, Galucio and Gabas Jr. (2008: 1, our translation) write:

Brazilian regions occupied the longest have the lowest number of Indigenous societies and fewer native languages [...]. The native peoples surveyed occurred in greater numbers in remote areas, especially in the Amazon, where contact with the dominant society was more recent and less intense. In addition to being the region with the highest concentration of Indigenous populations in the country, Amazon also has great linguistic and cultural diversity. The region has more than two-thirds of the Indigenous languages spoken in the country.

Brazilian Indigenous languages are generally classified into two big linguistic branches: Macro-Jê and Tupi; four linguistic families: Arawak, Karib, Pano and Tucanoan; six mid-size language families: Arawá, Katukina, Maku, Nambikwara, Txapakura, and Yanomami; three smaller families: Bora, Guaikuru, and Mura; and seven isolated languages: Aikanã, Kanoê, Kwaza, Irântxe, Mynký, Trumai and Tikuna. There are two additional Indigenous groups in the northern Amapá region, Galibí-Marwórno and Northern Karipúna. Karipúna is a creole language, influenced by the French language from French Guiana (Moore, Galucio and Gabas Jr., 2008).

There is no consensus concerning the number of Brazilian Indigenous languages, owing in part to the different criteria used to determine this figure. Moore and Gabas Jr. (2006), for example, consider that this vagueness is related to uncertainty about identifying an Indigenous group as speakers of an autonomous language or of a dialect of a related language. According to these authors, linguists generally take into consideration the mutual intelligibility criterion to characterize language varieties as dialects of the same language or not, whereas common sense considers mainly identity and political distinctions as criteria. In this sense, the selected criterion interferes directly in counting the number of Brazilian languages. Another issue related to the exclusion of certain languages in this count is the lack of information. The literature on this subject presents numbers which vary from 150 to 274 Brazilian Indigenous languages. Moore, Galucio and Gabas Jr. (2008) argue that the impossibility of defining the number of Brazilian Indigenous languages is due to a lack of systematic data collection applying collectively agreed methods. Although it is frequently mentioned that the number of Brazilian Indigenous languages is 180, this number could not pass 150 if the mutual intelligibility criterion was taken into consideration. Another fact is the emergence of new previously unknown languages, or by the identification of speakers of a language considered extinct.

Another challenge is in determining the number of speakers of each Indigenous language. In the past, the number of individuals was taken into consideration instead of the actual number of speakers of certain Indigenous people. This is a problem, since there are some Brazilian Indigenous groups in which almost all people speak the native language; on the other hand, there are several groups with a rather low number of speakers (Moore and Gabas Jr., 2006; Moore, Galucio and Gabas Jr., 2008). 
An additional relevant issue in counting the Indigenous language speakers is the degree of transmission of the language. According to Moore and Gabas Jr. (2006), the degree of transmission of the Indigenous language to children is what fundamentally determines the future of this language. However, a systematic study on this subject has not yet been done in Brazil.

Moore, Galucio and Gabas Jr. (2008) present a general view on the situation of Brazilian Indigenous languages, pointing out that all of them are endangered, and some are in risk of disappearing soon

(Figure 1). From the approximately 150 languages they counted, at least $21 \%$ are seriously endangered due to the low number of speakers and the low rate of transmission for future generations. This situation is even more worrying because of the limited number of studies on the most endangered languages.

These languages are known only partially, and almost half of them has few or almost no research done on them. The degree of scientific knowledge on Brazilian Indigenous languages, considering only languages that probably still have speakers, is approximately as follows (Moore, Galucio and Gabas Jr., 2008: 2, our translation):

- $13 \%$ have a full description

- $38 \%$ have an advanced description

- $29 \%$ have a still incipient description

- $19 \%$ have little or no significant scientific description

Thus, there is a need for urgent action to be taken to engage and revitalize Brazilian Indigenous languages. The case study that will be presented next is an attempt to share the experience about constructing tools and developing strategies to engage with and maintain the Apurinã language.
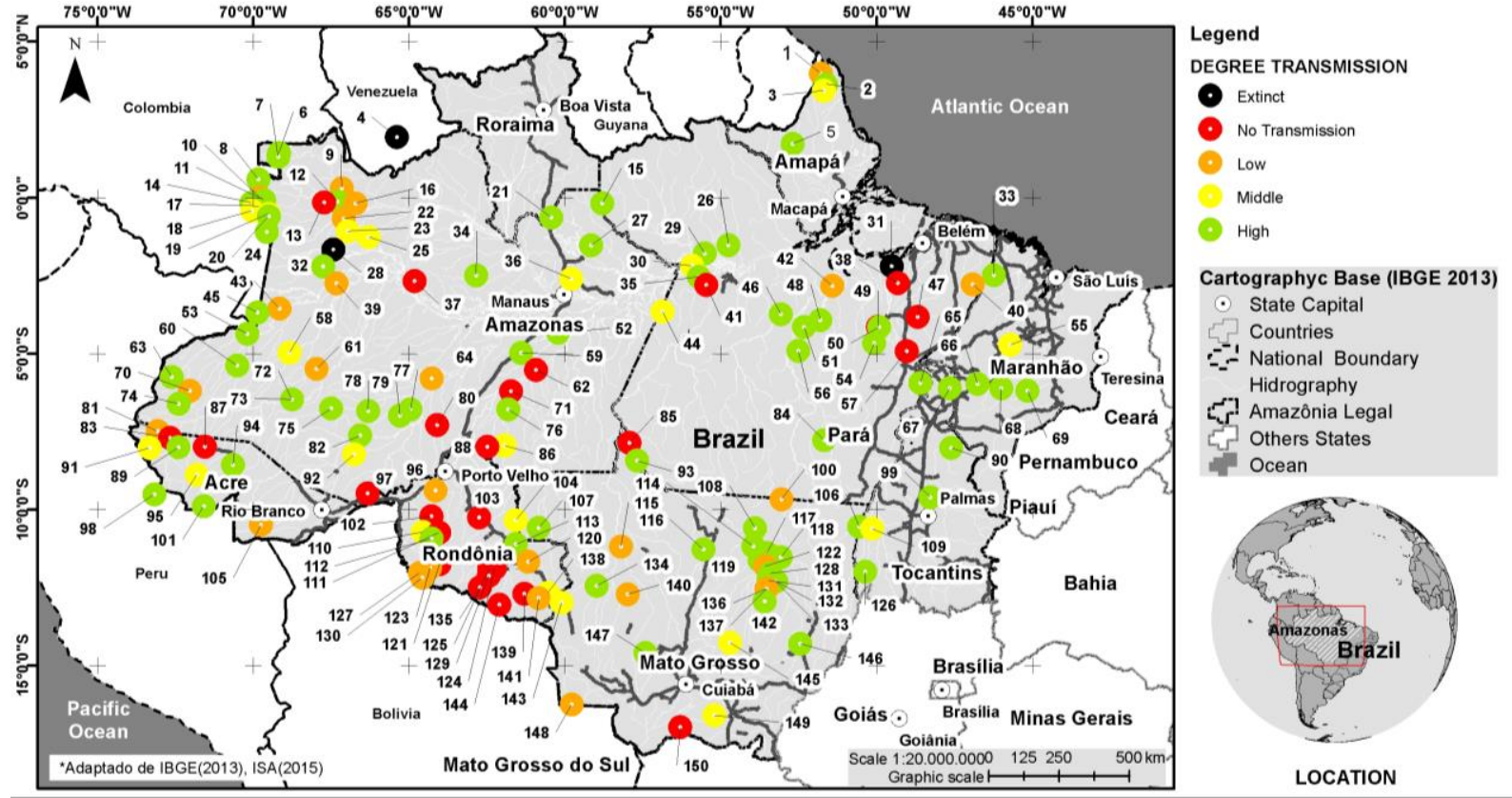

1 Galibi

2 Palikur

3 Karipuna of Amapá

4 Baré

5 Wajampi

6 Siriano

7 Cubeo

8 Hupda

9 Bará

10 Barasano

11 Karapaná

12 Dãw
13 Arapasso

14 Macuna (Yebá-masã)

15 Hixkaryana

16 Tariana

17 Yuhupdeh

18 Tuyuca

19 Waíkana

20 Desana

21 Waimiri-Atroari

22 Warekena

23 Nheengatú

24 Kotiria (Wanáno)
25 Nadëb

26 Apalaí

27 Wai wai

28 Kaixana

29 Zo'é

30 Kaxuyana

31 Turiwára

32 Baníwa

33 Ka'apor

34 Yanomami

35 Tiriyó

36 Wapishana
37 Muinane

38 Anambé

39 Kokáma

40 Tembé

41 Wayana

42 Krenák

43 Kambeba (Kokama)

44 Sataré Mawé

45 Ticuna

46 Arara

47 Amanayé

48 Galibi Maworno
49 Xipáya

50 Asurini of Tocantins

51 Asuriní of Xingu

52 Macuxí

53 Matsis

54 Parakanã

55 Guajajára /

Tenetehara

56 Araweté

57 Gavião Parkatejé

and Kykateyé

58 Ingariko 


\begin{tabular}{|c|c|c|c|c|}
\hline 59 Taurepang (Pemóng) & 78 Suruwaha & 97 Kaxarari & 115 Rikbaktsá & 134 Enawenê-nawê \\
\hline 60 Korúbo & 79 Jarawara & 98 Ashaninka & 116 Kayabí & Salumâ \\
\hline 61 Tosohon-dyapa & 80 Juma & 99 Xerénte & 117 lkpeng & 135 Arikapú \\
\hline 62 Mura & 81 Poyanáwa & 100 Terena & 118 Kisidjê (Suyá) & 136 Mehinaku \\
\hline 63 Matses & 82 Jamamadi & 101 Yaminawa & 119 Nahukwa & 137 Yawalapití \\
\hline 64 Paumarí & 83 Nawa & (Jamináwa) & 120 Kwaza & 138 Aikaná \\
\hline 65 Suruí of Tocantins & 84 Kayapó & 102 Karipuna & 121 Kujubim & 139 Wayoró \\
\hline 66 Krinkatí & (Mebêngôkrê) & 103 Urupá & 122 Trumai & 140 Irantxe \\
\hline 67 Apinajé & 85 Apaiká & 104 Káro (Arara) & 123 Makurap & 141 Akuntsú \\
\hline 68 Canela Apaniekrã & 86 Tenharím & 105 Machineri & 124 Tupari & 142 Awetí \\
\hline 69 Canela & 87 Arara (Shawãdawa) & 106 Tapirapé & 125 Puruborá & 143 Nambiquara \\
\hline Ramkokamekrã & 88 Jiahui & 107 Cinta-Larga & 126 Karajá & 144 Mekéns \\
\hline 70 Kulina & 89 Katukina of Acre & 108 Panará & 127 Jeoromitxi & 145 Bakairí \\
\hline 71 Torá & 90 Krahô & 109 Avá-Canoeiro & 128 Matipu & 146 Xavánte \\
\hline 72 Kanamarí & 91 Shanenawa & 110 Wari' & 129 Aruá & 147 Paresí \\
\hline 73 Katukina of Biá & 92 Apurinã & 111 Oro Win & 130 Kanoé & 148 Chiquitiano \\
\hline 74 Marubo & 93 Mundurukú & 112 Uru-eu-wau-wau & 131 Kamayurá & 149 Boróro \\
\hline 75 Dení & 94 Kulina & (kawahib) & 132 Kuikúru & 150 Guat \\
\hline 76 Pirahã & 95 Yawanawa & 113 Suruí Paiter & 133 Kalapalo & \\
\hline 77 Banawá & 96 Karitiána & 114 Tapayuna & & \\
\hline
\end{tabular}

Figure 1. Indigenous languages of the Brazilian Amazon and neighboring area classified in terms of their degree of vitality. [The information provided in the map is primarily based on Moore et al (2008), with some updates. This map was made possible thanks to the great effort by Bruna Fernanda S. de Lima-Padovani in designing the map from scratch, with the technical assistance of Ronaldo Almeida. We wish to thank the colleagues Bruna Franchetto, Hein van der Voort, Vilacy Galúcio, Ana Paula B. Brandão, and Angela Chagas for taking the time to share some more up to date information about some of the languages in the map.]

\section{Apurinã language and diversity}

Apurinã is one of approximately forty still extant Arawak languages (Aikhenvald, 2005). It is spoken by the self-denominated pupỹkarywakury people, and they live along several tributaries of the Purus River, in Southeastern Amazonas state, Brazil, and in a few communities along the BR-317 highway, which links the cities of Rio Branco and Boca do Acre. There is a significant number of Apurinã individuals living outside Indigenous communities, in Rio Branco (Acre state), Boca do Acre, Pauini, Lábrea, Canutama, Tapauá, Manacapuru, and Manaus (Amazonas state). In addition, there are some Apurinã people living in the territories of other Indigenous groups (Paumari, Jamamadi, Torá, and Cinta Larga). Currently, the Apurinã population has approximately 6,842 individuals (IBGE, 2010 based on color or ethnicity criteria) dispersed over several communities. The following map (Figure 2), presents the spatial distribution of some of the Apurinã communities along the Purus Basin. 


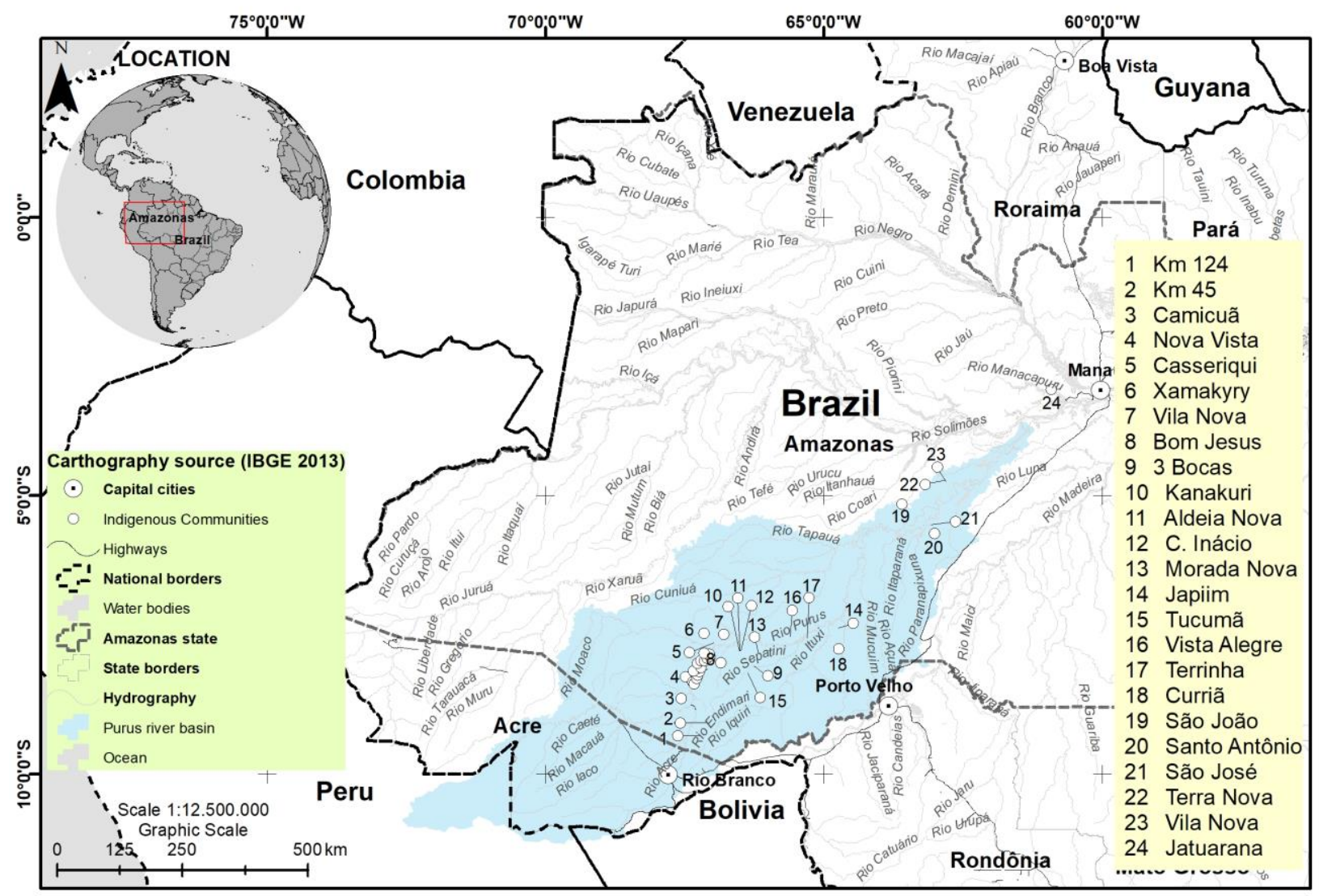

Figure 2. Approximate location of Apurinã communities in the Purus Basin (Lima-Padovani 2016, translated from Portuguese by Cinthia Samara Oliveira Ishida).

Formerly, the Apurinã people lived in the Central Purus sub-region, but now, being a nomadic group, their territory is, probably, more scattered than in the past, and they also live in the Lower Purus subregion, from the Amazonas state to the Rondônia state.

It is difficult to know the exact number of Apurinã people (as it is not possible to know exactly the total number for the Brazilian Indigenous population as a whole), mainly because of constant migration movements, motivated by several factors, most frequently internal conflicts. The main strategy to escape from such conflicts is to move to communities far away from the original one, or to form a new community. For example, one of the Apurinã consultants that took part in this study was born in a community on the Seruini River (a Purus River tributary); when he became an adult, he and his family went to another community, Nova Fortaleza; some years later; part of the members of this new community, including our contributor, migrated further to a new area, Vista Alegre. About three years later, he founded yet another community, Terrinha. (Nova Fortaleza, Vista Alegre, and Terrinha are located in the Indigenous territory of the Paumari of Marahã Lake, an area neighboring lands traditionally occupied by the Paumari.) Today, he lives in Lábrea City part of the time, as well as in his Indigenous community. Apurinã individual's history has always been marked by several changes and migrations. This is a general characteristic of the Apurinã that helps to explain their current geographic spread.

The geographical spread caused by mobility and migration over a period of several generations has contributed to dialectal variation, characterized by different pronunciations, different word internal structures, and different vocabulary (Barreto, 2007; Lima-Padovani, 2016). For example, the ways in which Apurinã speakers pronounce the Apurinã word for 'water' in different communities are shown in Figure 3. 


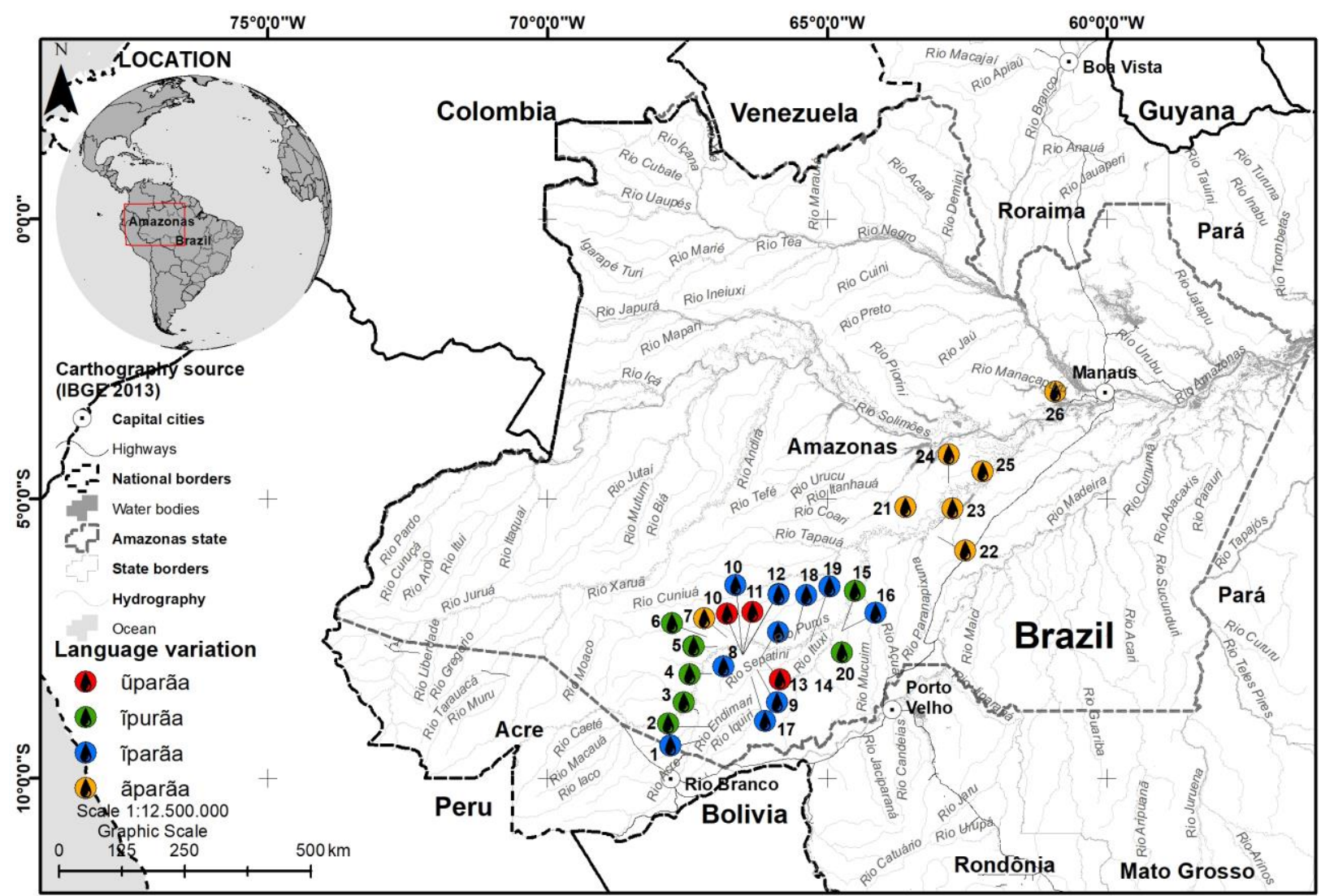

Figure 3. Variation in pronouncing the word for 'water' in the Apurinã language (Lima-Padovani 2016, translated from Portuguese by Cinthia Samara Oliveira Ishida).

There are four different variants to the word for 'water' in Apurinã: /ãparãa/, /ĩparãa/, /ĩpurãa/, e /ũparãa/, and each is associated with a different community. The form ĩparãa is the most recurrent in the Purus region, being attested in ten communities, predominantly in the Central Purus sub-region. The variant ĩpurãa, with 7 occurrences, is the second most frequent one, located in the Upper Central Purus subregion; this variant was attested in communities 16 (Japiim) and 20 (Curriã) in the map above, located in the Central Purus sub-region. The distribution of ĩpurãa is due to the migration of members originally from the Upper Central Purus, number 4 on the map (Tacaquiri, TI Peneri), to the Central Purus. The variant ũparãa was attested in the communities numbered 10 (Kanakuri, TI Tumiã), 11 (Aldeia Nova, TI Tumiã), and 13 (Morada Nova, TI Acimã), in the map above. In communities 10 and 11, it occurs only in the speech of younger individuals. Finally, the variant ãparãa, with 6 registers, is located predominantly in the Lower Purus sub-region, for both young and old speakers. Community number 7 on the map, the Vila Nova community (TI Catipari/ Mamoriá), is the only place outside lower Purus where the ãparãa form was attested. It is important to mention that individuals from Vila Nova migrated to Jatuarana over 40 years ago. Variation is common for spoken languages, but based on the information gathered by the authors, it can be proposed that these individuals brought the variant ãparãa from the upper to the lower Purus to their sub-region, where it was disseminated.

According to Lima-Padovani (2016), a number of words have been borrowed from Portuguese. These loan words refer to items that were not part of their pre-contact universe, coming into Apurinã culture through contact with Portuguese speakers. It was necessary, in this sense, to create (or to adapt phonologically) lexical forms to label these new concepts; the solution for this issue, for some Apurinã individuals, was through borrowing from Portuguese words. However, some other individuals preferred to use another strategy, namely the creation of neologisms using existing Apurinã words, through compound 
formation, to refer to the new concepts; this led to the emergence of a wide range of variation in Apurinã, as shown in Figure 4.

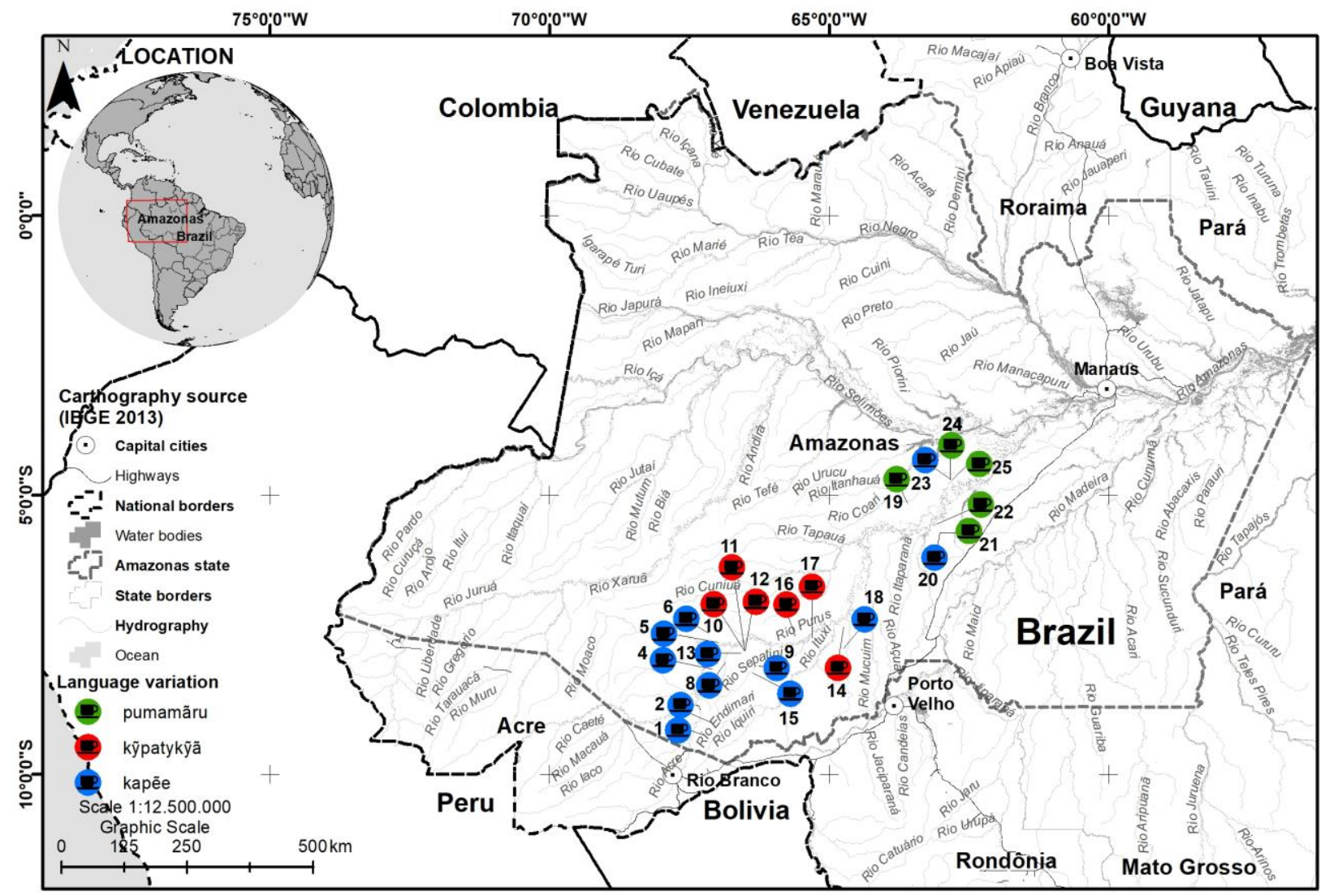

Figure 4. Variation in the word for 'coffee' in Apurinã (Lima-Padovani 2016, translated from Portuguese by Cinthia Samara Oliveira Ishida).

There are three variants for the word 'coffee': pumamãru (pumamaru = 'black' + $\tilde{a}=$ 'classificatory noun for liquid substances'), occurring in 5 places; kỹpatykỹã (kỹpaty = 'wild banana tree' + $\tilde{a}=$ 'classificatory noun for liquid substances'), occurring in 6 places; and kapẽe (loan word from Portuguese, adapted to Apurinã phonology), with a broader distribution, occurring in 12 places. In the lower Purus, where the dominant variant form is pumamaru, the variant kapẽe was also attested. This last form was supplied by community leaders from this region, which has more contact with speakers from different regions. This fact could explain the occurrence of this variant in the lower Purus. It suggests that speakers who have chosen Portuguese words, and adjusted these words to Apurinã phonology to name objects new to their culture, had more extensive contact with the Portuguese language and, thus, presented a greater degree of bilingualism. Therefore, in other to preserve their language, some Apurinã borrowed words from Portuguese, while others did not. Although, initially, outside contact was a result of the rubber boom and consequent interaction with Non-Indians coming from the Northeast region, later contact with outsiders became permanent as result of the frequent visits to the cities, as the Apurinã people became dependent of products such as clothes, salt, sugar and ammunition etc., only found in the city.

It is estimated that the Apurinã language is spoken roughly by $10-20 \%$ of the population, with different degrees of fluency. Some of the Apurinã are bilingual, with Portuguese being the prevalent language, rather than Apurinã, in most communities. Such communities, as mentioned before, show different degrees of bilingualism, some using exclusively Portuguese, and a minority using Apurinã as the main language. Therefore, it can be concluded that Apurinã is an endangered language, since only a small portion of the population still speaks the native language as the first language. In general, only older 
individuals speak Apurinã actively; younger individuals, in most cases, can comprehend, or know part of the lexicon, as passive speakers of the language; children, in general, at the present time, do not learn Apurinã as a first language. Thus, Apurinã people can be organized into four groups, in relation to the sociolinguistic situation, as follows:

1. Mostly monolingual groups in Apurinã;

2. Bilingual groups, in which the Apurinã language is still productive, being used in daily activities, internal meetings, and rituals;

3. Groups where Apurinã is used only by elders;

4. Groups in which Apurinã was replaced by Portuguese among the majority or even all individuals who (almost) do not have knowledge of their native language.

The Apurinã sociolinguistic situation reflects the Apurinã people history, their life and survival in the forest, their internal conflicts, and the massive occupation of their territories by non-Indigenous people at the time of latex extraction. The contact with non-Indigenous individuals resulted in exploitation and violence against the Apurinã people. According to personal reports given by some Apurinã individuals, they were forbidden by rubber tappers to speak their own language, their life in community houses ended, and they adopted the economy in which they worked for a patron receiving products for their produce. As Apurinã were heavily oppressed, their language and knowledge were regarded as primitive and without a value, this context creates a sense of devaluation of Apurinã identity, and causes detachment from their traditional activities and their language.

All the factors mentioned in this section contributed to the language shift toward Portuguese, and these factors, considered as a whole, constitute the sociolinguistic profile of the Apurinã people.

\section{Engaging with a language in an Apurinã Socio-Cultural Context}

The writing and standardization of the Apurinã language for didactic materials have been challenging because of the large variation, involving many groups of Apurinã with different verbal skills, and oppressive language contact with the Portuguese language. On one hand, colonization processes have hindered Apurinã parents' motivations to speak their Indigenous language and teach it to their children, because of the legacy of painful assimilation experiences. The training of Indigenous teachers in the region is still very recent, and mainly provided by the local secretary of education and the project Pirayawara directed to more advanced teachers. These actions have obtained too little state funding, and sometimes the educational activities have had been interrupted even for years. Meanwhile, educational professionals have had some little knowledge of Indigenous socio-philosophies, and as training courses have involved different ethnic groups, with languages and cultures, each group has had little experience with the teaching of their own language, traditional knowledge, and ways of learning. Furthermore, via the national schooling system, only very few Apurinã teachers living in villages have gained some sort of literacy skills to provide proficiency in reading and writing in Portuguese, and none in teaching those in Apurinã. This did not help improve the current number of actual Apurinã speakers, especially children. Aside from that, in spite of the fact that the constitution of 1988 and several laws defined in the 1990s guaranteed the Indigenous population the right to education (MEC, 2016), the state has not given adequate and sufficient support for Apurinã's education either in their own language or in multicultural terms. As a result, most Apurinã schools have followed the common state education curriculum. On a global scale, schooling, especially one that does not acknowledge cultural differences, is affecting the world's linguistic and cultural diversity. This has not only weakened Indigenous languages, but also their oral traditions, and their ways of learning that is typically not literal, text based or linear.

In the region where Apurinã people currently live, the Central Purus, Indigenous people have often been discriminated against not only in the area of education, but also in health services and other matters. In the state of Amazonas and Acre, the presence of pro-Indian associations has a long tradition, but in the Central Purus their activities are much more recent. Moreover, in this region, administrative and economic power has been in the hands of a few land owners and merchants, who have rarely treated Indigenous population as equal. Several Apurinã people underline that in some contexts, non-Indigenous people still tell them not to speak their Indigenous language. Their language is referred to in Portuguese as gíria (slang), and overall this has often affected people's use of their Indigenous language. Even those Apurinã 
who have lived in forest environments are surrounded by non-Indigenous colonizers who have frequently considered local Indigenous population to be inferior. The long history of colonization has not only affected Apurinã's language skills, but also attitudes towards Indigenous traditions and knowledgeproduction. Altogether, this has made Apurinã non-literal learning processes of oral history, shamanism, rituals, and generally reproducing traditional knowledge in several villages a complex issue. Furthermore, the language has no media outlet, such as radio, TV, web page or newspaper, since literacy has been only recently started to develop in their traditional language.

However, several Apurinã still have rich oral traditions and environmental knowledge, and several things can only be expressed in their own language, such as some master spirits of entities, illnesses caused by these nonhuman agencies (Virtanen, 2015a). Some Apurinã, with strong motivations to use and learn their language often refer to their language by the Apurinã term Pupỹkary sãkyre, literally "Apurinã's language," which conveys and contains emotions of respect and pride. Among others, Woolard and Schieffelin (1994) have noticed that larger social processes are linked to language, such as identity, aesthetics, epistemologies, and morality. It can be noticed that language learning needs to be connected to these issues in order to remotivate language learning. Therefore, Indigenous ways of knowing, arts, and local contexts should be embedded in the teaching and learning of Indigenous language. Having said this, this in itself does not save language vitality, as young people make their own language choices at an early age.

In the collaborative efforts established, by combining different actors, including linguists, sociolinguists, ethnographers, community members, Apurinã teachers, as well as local governmental and nongovernmental organizations, there were some initiatives in designing teaching materials that take into account the past and present social realities in which the Apurinã live. The texts for teaching materials are produced by Apurinã narrators and have been revised in Apurinã language workshops organized with the communities, as explained in the following section. Although the social, environmental, and cultural learning contexts have been acknowledged in the efforts to revitalize the Apurinã language, the long colonial history can still be seen to affect the current processes of learning.

\section{Language Vitality and Collaborative Efforts}

As mentioned above, Apurinã is one of less than two hundred distinct Indigenous languages spoken in Brazil, out of a few thousand spoken at the time of the European arrival in 1500. Most of the still surviving languages are spoken in the Amazon region, particularly by those groups which are more isolated and with less contact with the outside society. Although unavoidable, contact with the outside world and its dominant language often tends to lead to the extinction of minority languages. The Apurinã were not among the first people in Brazil to be contacted by Europeans. They were not mentioned, for example, in de Acuña (1859: 107-108), although he mentions other groups in the Purus River region. The first documents mentioning the Apurinã are Chandless (1866), the work of Manoel Urbano da Encarnação, Labre (1889:496), Ehrenreich (1897:59-60), Steere (1901), and Koch-Grünberg (1919). Thus, we can estimate the first contact of Apurinã with members of the dominant society as no more than 200 years ago. More systematic information about the language appears in the work of the missionaries Polak (1894) and Pickering and Pickering (1964), Pickering (1971, 1973, 1974, 1977a, 1977b, 1978), and Aberdour (1985). More comprehensive studies on the language started with Facundes (1994, 2000) and continue to the present time with Facundes's students and colleagues at Universidade Federal do Pará, in Brazil. The main anthropological works are Schiel $(2000,2004)$ and, more recently, Virtanen $(2015 a$, $2015 b)$. Together, these linguistic and anthropological studies have furnished the production of school materials to serve as tools in language engagement and revitalization.

The first attempt to produce materials to teach the Apurinã language was done by the missionary linguist Wilbur Pickering, from the former Summer Linguistic Institute (SIL), when he produced a number of small sets of literacy booklets (Figure 5A) to introduce writing in the Apurinã language. Later, Pickering was replaced by two other missionaries, also from SIL, Kathie Aberdour and Judith King, both with less linguistic training than Pickering. Although Aberdour and King continued the tradition of using booklets to teach Apurinã writing, their focus was more on their religious mission than on contributing to maintaining the language as part of the Apurinã culture. To this effect, the Christian Bible was translated into Apurinã, and a number of booklets was produced containing Apurinã versions of chapters of the Bible. In fact, they 
did what they could to introduce Christian beliefs into the Apurinã society, for which the literacy materials were a mere tool to later usher in the Bible translation. Having said that, it is necessary to acknowledge that, although language preservation was not a goal in itself, the fact that the Apurinã language was used as an instrument of religious proselytism did in fact contribute to language maintenance in the communities where the missionaries were present, even if at the price of some conflicts involving converts and non-converts in the Apurinã villages, and major changes in some of their cosmological visions of the universe. To this effect, today it is not uncommon to find in these communities where missionaries were present individuals who are fluent Apurinã speakers, but who have not learned the most important narratives of the rich Apurinã oral history. 
The literacy material produced by missionaries quickly disintegrated, due to the local weather conditions. Few communities had such material, although it could be more frequently found in places where the

A

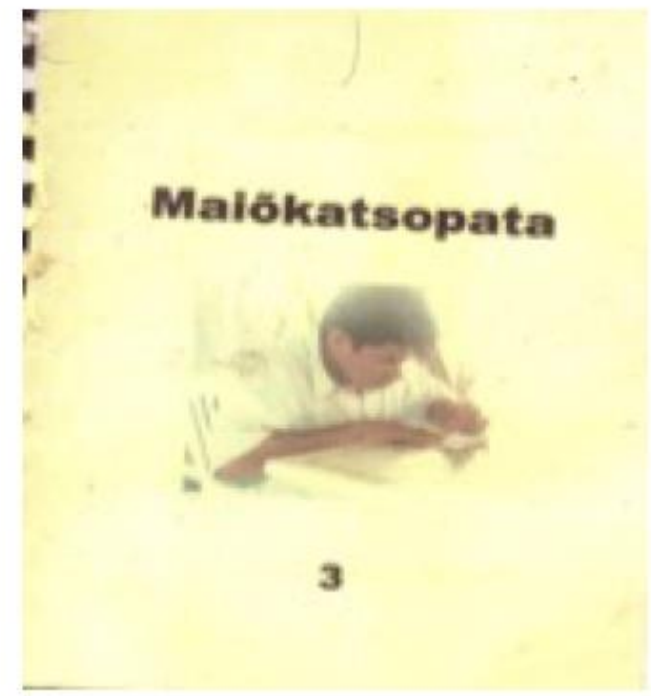

B

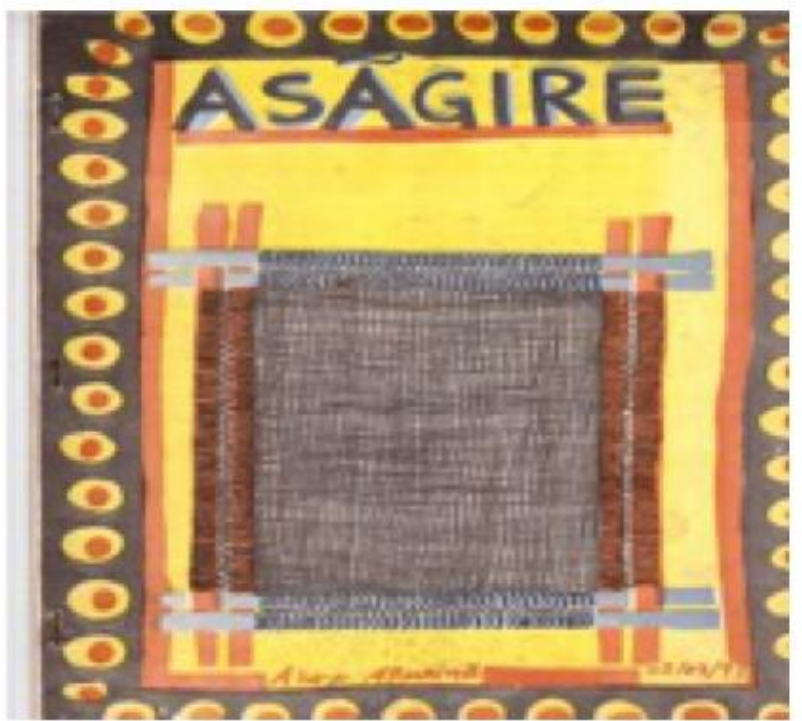

C

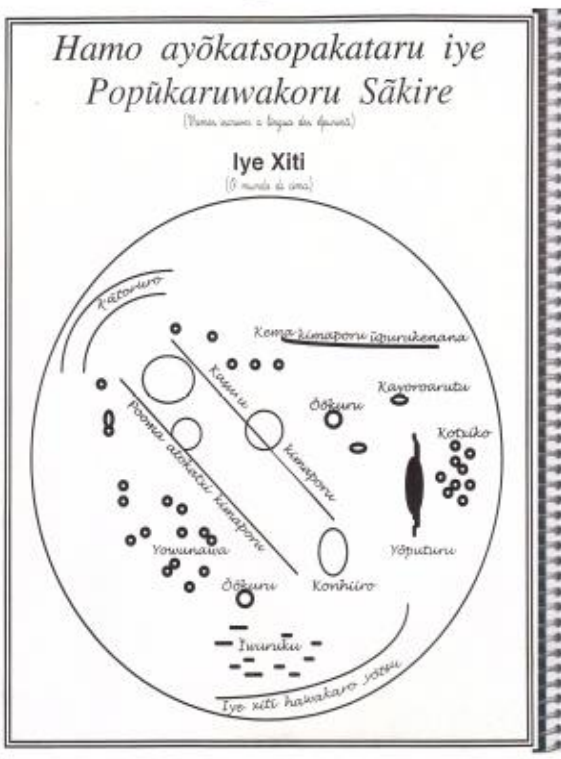

D

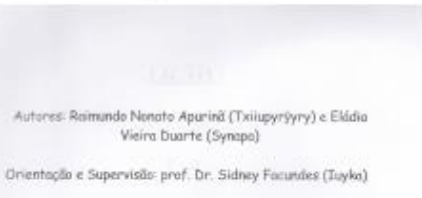

ESCREVENDO EM APURINÃ

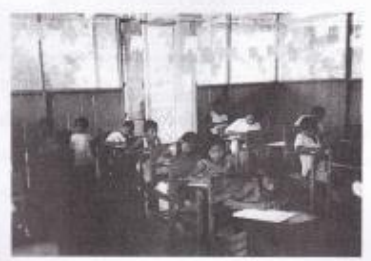

E

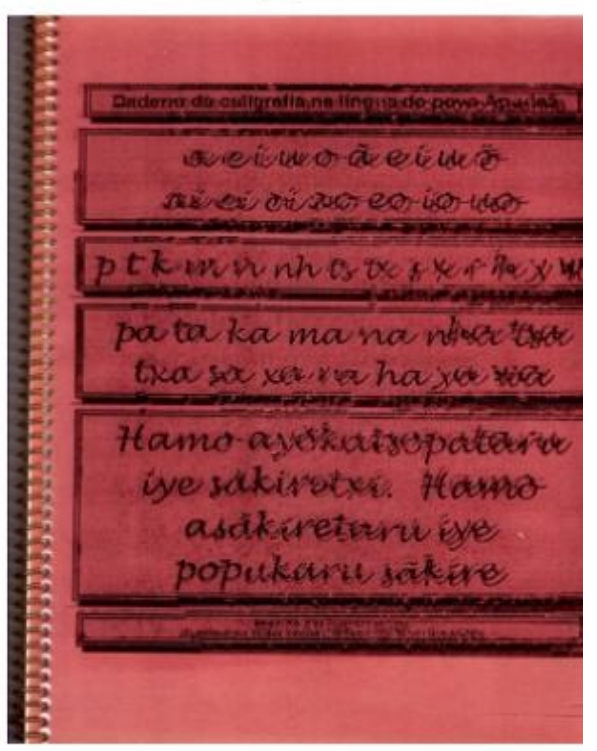

Figure 5. (A) Missionary literacy booklet "Let's Write"; (B) Booklet by the Pro-Indian Commission "Our Language"; (C) First booklet produced by Facundes 'Let's Write the Apurinã Language"; (D) "Writing in Apurinã"; (E) Apurinã Handwriting.

missionaries had lived, such as in the Nova Fortaleza or Itaboca communities. Later, in 1993, the nongovernmental organization, the Pro-Indian Commission (Comissão Pró-Índio) in Rio Branco/Acre produced another booklet, entitled Asãgire, "Our Language", to introduce writing in the Apurinã language (Figure 5B). The main goal of the booklet was not to provide technical material, but more symbolically to increase the value and estimation of the Apurinã language and culture. However, the Apurinã individuals who provided the language data were not fluent speakers of the language. As a result, the problems with 
the content of the material led to its rejection by the Apurinã communities once fluent speakers realized that what was written there did not correctly represent the way they spoke. The fact that the language in this booklet was written using an orthography that wrote sounds that were not contrastive in the language (i.e. not phonemes), but were in fact free variants of the same phonemes, created problems because speakers did not understand why two different letters were used to write what to them sounded the same.

In 1990, in his first contact with the Apurinã leadership of the Boca do Acre region, Antônio (Preto) Apurinã, then president of the Union of Indigenous Nations-UNI (União das Nações Indígenas) of Acre, Sidney Facundes accepted the condition that his linguistic research on the Apurinã language had to contribute to its survival and maintenance. After his first trips, a new orthography for the language was proposed and implemented in the first literacy material (Figure 5C), "Hamo Ayõkatsopatary iie Popũkary Sãkire" (Let's Write in Apurinã), with a cover page using a drawing of the map of the sky made by the Apurinã themselves. The orthography used in this literacy book was based on the phonological system of the language, and with as much use as possible of letters from Portuguese. Quickly, however, it became clear that the Apurinã who were monolingual in Portuguese pronounced "u" with a Portuguese accent, that is, as [u] rather than [i]. This led to a revision in the orthography, such that nowadays [i] is written "y," $[u]$ is written " $u$," and [j] is written "i," since most of them spoke Portuguese, but not Apurinã.

This first literacy book aimed at self-teaching the written language, since at that time there was less interest among Apurinã youngsters in learning the Apurinã language or learning to write in it. As this interest grew more and more, there was also an increase in the demands to write and have language teaching materials in Apurinã. As an attempt to answer that demand, Facundes, together with a team of young students from Universidade Federal do Pará (UFPA), Belém, Brazil, produced other books which could be used by Apurinã people interested in teaching the language and its writing in a school classroom (Figure 5D). Although none of these books was made widely available, due to lack of funding, they were informally copied and distributed to whomever, among Apurinã individuals, showed an interest in using them, thus reaching some of the communities in the regions surrounding the Pauini and Lábrea counties. A later analysis of the reaction to the materials in different communities allowed the identification of the degree to which speakers were sensitive to dialectal distinctions in the language. Such differences were hardly object of any discussion in personal everyday oral interactions among people from different communities; however, once such linguistic differences came to be represented in writing, speakers became much more aware and critical of language varieties different from their own. This was the first of two important issues that came to light once the language materials, then representing only one of several language varieties, became available to a wider spectrum of speakers of different varieties in different communities. This issue required addressing.

The second issue which arose from these literacy materials being exposed to speakers of different communities was that Apurinã teachers did not know how to use the materials in school classrooms as they lacked the required training. In response, new materials were produced (Figure 6A, B), which included activities and specific instructions and suggestions on how to teach each lesson from the textbook in the classroom. 

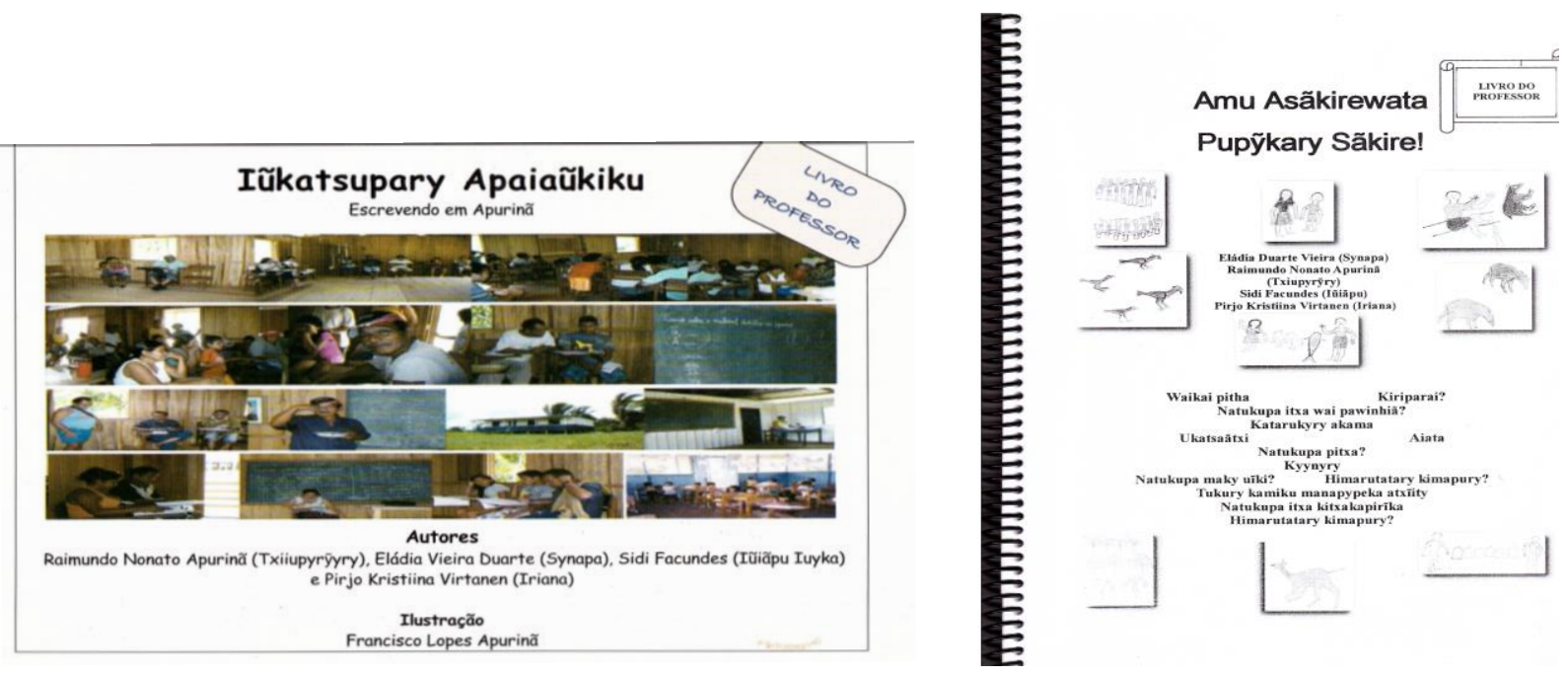

Figure 6. (A) lũkatsupary Apaiaũkiku (“Learning to write”); (B) Amu Asãkirewata - Pupỹkary Sãkire! (=Let's speak Apurinã).

At this point, the long-term ethnographic and anthropological knowledge that was available allowed the materials to be contextualized in Apurinã's socio-cosmology and environment. These more recent materials also addressed the issue of language variation, making use of the research on Apurinã language variation presented, especially, in Barreto (2007) and Lima-Padovani (2016).

Once the issues of language variation and teacher instruction were addressed in the teaching materials, the expectation was that such problems had been at least partially solved. However, in discussion with a number of Apurinã teachers and Apurinã individuals interested in becoming language teachers, it soon became clear that it was impossible for teaching materials to replace proper actual in-person language teaching training in places where Apurinã languages were little or not at all spoken because of shift towards Portuguese. Apurinã individuals required proper in-person introduction to the teaching material on how to use it, aside from the instructions written in the teaching materials themselves. Finally, the current stage of the work was reached, wherein Apurinã language workshops were organized to involve teachers and community language authorities in different communities, a work that still requires much time and financial resources. In these workshops, the team of researchers presented and discussed with the Apurinã teachers and language authorities of each community the content of the textbooks and strategies to teach the language in the school communities. These workshops have been organized by the Apurinã research team, the main Indigenous organization of the region (FOCIMP), the regional Indigenous political representative organization, the Indigenous Missionary Council - CIMI (Conselho Indigenista Missionary) in Lábrea, with the collaboration of the federal branch for Indigenous peoples' affairs (FUNAI) and, sometimes, also of local authorities. Until today the teaching material has not been published by the government, because of constant changes in local secretaries of education.

\section{Final Remarks}

Although not providing far-reaching solutions to the problem of language endangerment, the various experiences which led to the Apurinã language workshops have provided important insights into strengthening an endangered language. The experiences showed that respecting and taking into consideration the diversity of the language helped in adopting the teaching materials, sometimes going against what linguistic practicality and standardization might have suggested. Moreover, using language teaching materials in Indigenous schools does require a certain degree of knowledge of pedagogical techniques, which do not necessarily evolve naturally, and it is crucial to involve and base the teaching in 
the traditional practices of Indigenous ways of knowing as well as to Indigenous socio-philosophies. Moreover, wherever possible, the members of the Indigenous community should be involved and should regard themselves as (co-)authors of the materials. Languages are always used with some purpose in mind, and, although language teaching can and must be used also to tell the history, present and values of a people, teaching a language only in domains which are no longer part of communities' reality is unlikely to offer a community what they need in order to keep them using the language. In the communities with little knowledge of Indigenous language, the use of language should not be restricted only to school, but even parents should be active in interacting with the child in the Indigenous language. Aside from work with language, there must be new initiatives and the creation of new language domains, such as national health care, Indigenous politics, new genres of music, and social media (see Virtanen, 2015c), so that the language can be what languages should be, namely dynamic. All these public spaces, created for an endangered oral language, shall be based on Indigenous collaboration as well as support from local governments and other collaborators.

\section{References}

Aberdour, K. (1985). Referential Devices in Apurinã Discourse. Porto Velho, Working Papers, ed. David Fortune, 43-91. SIL; Brasília.

Aikhenvald, A. Y. (2005). Arawak. In P. Strazny (ed.), Encyclopedia of Linguistics, 81-84. New York: Fitzroy Dearborn.

Barreto, É. L. (2007). Variação em Apurinã: Aspectos Linguísticos e Fatores Condicionantes. Master's thesis. Belém: Universidade Federal do Pará.

Chandless, William (1866). Ascent of the River Purus. Journal of the Royal Geographical Society 36, 86118.

de Acuña, C. (1859). New Discovery of the Great River of the Amazon. In C. R. Markham (ed.), Expeditions into the Valley of the Amazons, 1539, 1540, 1639 (47-134). Translated from the Spanish edition of 1641. New York: Burt Franklin.

Ehrenreich, Paul. (1897). "Materialen zur Sprachenkunde Brasiliens: Vokabulare von PurusStämmen." Zeitschrift für Ethnologie 29, 59-71.

Facundes, Sidney S. (1994). Noun Categorization in Apurinã (Maipuran). Master's thesis. University of Oregon, Eugene.

Facundes, Sidney S. (2000). The language of the Apurinã people of Brazil (Maipure/Arawak). PhD dissertation, University of New York, Buffalo.

IBGE - the Brazilian Institute of Statistics and Geography (2010). Censo 2010.

http://www.censo2010.ibge.gov.br/terrasindigenas/, accessed September 15, 2016.

Koch-Grünberg, von Theodor (1919). Ein Beitrag zur Sprache der Ipuriná-Indianer, Rio Purus, Brasilien. Journal de la Société des Américanistes 11, 57-96.

Labre, Antônio Rodrigues Pereira (1889). Colonel Labre's Explorations in the Region between the Beni and Madre de Dios Rivers and the Purus. Proceedings of the Royal Geographical Society and Monthly Recording of Geography 11(8), 496-502.

Lima-Padovani, B. F. (2016). Levantamento Sociolinguístico do Léxico da Língua Apurinã e sua contribuição para o conhecimento da cultura e história Apurinã (Aruák). Master's thesis. Belém: Universidade Federal do Pará. 
MEC-Ministério da Educação (2016). Educação Indigena. http://portal.mec.gov.br/educacao-indigena, accessed December 4, 2016.

Moore, D. and Gabas Jr., N. (2006). O Futuro das Línguas Indígenas Brasileiras. In L. Forline, I. Vieira and R. Murrieta (Eds.), Amazônia além dos 500 Anos (pp. 433-454). Belém: Museu Paraense Emílio Goeldi.

Moore, D., Galucio, A. V. and Gabas Jr., N. (2008). O desafio de documentar e preservar as línguas amazônicas. Scientific American Brasil - Amazônia (A Floresta e o Futuro) 3, 36-43.

Pickering, Wilbur (1971). Apurinã Grammar. Arquivo Linguístico Nr. 008. Brasília, D.F., S.I.L.

Pickering, Wilbur (1973). Command in Apurinã. Arquivo Linguístico Nr. 006. Brasília, D.F., S.I.L.

Pickering, Wilbur (1974). Gapping and Constituent Order in Apurinã. Arquivo Linguístico Nr. 005. Brasília, D.F., S.I.L.

Pickering, Wilbur (1977a). Interrogativos Apurinã. Translated by Daniel M. L. Arquivos de Anatomia e Antropologia, vol. II, 99-117.

Pickering, Wilbur (1977b). Relativização em Apurinã. Série Linguística 7, 127-140.

Pickering, Wilbur (1978). Negação no Apurinã. Arquivos de Anatomia e Antropologia, vol. III, pp. 233-261.

Pickering, Wilbur and Pickering, Ida (1964). Apuriná Phonemic Analysis. Arquivo Linguístico Nr. 004.

Brasília, D.F.

Polak, Jacob. E. R. (1894). A Grammar and a Vocabulary of the Ipuriná Language. Vocabulary Publication Fund, Nr. 1. London: Kegan Paul, Trench Trubner.

Schiel, J. (2000). Entre patrões e civilizadores : os Apurinã e a política indigenista no meio rio Purus na primeira metade do século XX. Master's thesis. Campinas: Unicamp.

Schiel, J. (2004). Tronco Velho - Histórias Apurinã. Doctoral dissertation. São Paulo: Universidade Estadual de Campinas.

Steere, Joseph Beal [1901] 1947. Tribos do Purus. Sociologia. Revista didática e cientifica, São Paulo, 11.

Virtanen, Pirjo Kristiina (2015a). Fatal Substances: Apurinã's Dangers, Movement, and Kinship. Indiana, 32, 85-103.

Virtanen, Pirjo Kristiina (2015b). "I Turn into a Pink Dolphin" - Apurinã Youth, Awiri, and Encounters with the Unseen. In C. J. Feldman-Barrett (ed.), Lost Histories of Youth Culture, 105-122. New York: Peter Lang Publishers.

Virtanen, Pirjo Kristiina (2015c). Indigenous Social Media Practices in Southwestern Amazonia - Digital Exchanges. AlterNative. An International Journal of Indigenous Peoples 11(4): 350-362.

Woolard, K. A. and Schieffelin, B. B. (1994). Language Ideology. Annual Review of Anthropology 23, 5582. 